\title{
Exploring the Link between Achievement Goals, Motivation, and Parental Expectations among University Students in Kosovo
}

\section{Albulene GrajCevci ${ }^{* 1}$ And Arif Shala ${ }^{2}$}

$\approx$ This paper sheds light on the link between achievement goals, motivation, and parental expectations in a sample of 600 students attending higher education institutions in Kosovo. Aside from exploring the stipulated link between the constructs, the research aims to discover whether cultural differences mediate expected results. The results proved that the mastery of goals positively correlates to intrinsic motivation in addition to which curiosity as a subscale of intrinsic motivation positively predicted preferences for the mastery of goals. As expected, performance-approach and performance-avoidance goals, correlated to extrinsic motivation with extrinsic motivation, successfully predict preferences for both types of performance goals. The data proved that among students in Kosovo, all types of goals correlated to intrinsic motivation. Achievement goals were differentiated in extrinsic motivation with mastery goals correlating rather weakly to only one subscale of extrinsic motivation.

Keywords: achievement goals, Kosovo, motivation, parental expectations

$1 \quad{ }^{\star}$ Corresponding Author. Professional Development Institute-PDI, Prishtina, Kosovo; grajcevci.albulene@pdi-ks.org.

2 Professional Development Institute-PDI, Prishtina, Kosovo. 


\section{Ugotavljanje povezav med cilji dosežkov, motivacijo in pričakovanji staršev študentov na Kosovu}

Albulene Grajcevci in Arif Shala

$\propto$ Prispevek osvetljuje povezavo med cilji dosežkov, motivacijo in pričakovanji staršev na vzorcu šeststotih študentov, ki obiskujejo visokošolske izobraževalne ustanove na Kosovu. Poleg raziskovanja povezav med omenjenimi konstrukti je bil raziskovalni namen tudi ugotoviti, ali kulturne razlike napovedujejo pričakovane rezultate. Rezultati so pokazali, da je obvladovanje ciljev pozitivno povezano $\mathrm{z}$ notranjo motivacijo, poleg tega pa je radovednost kot podraven notranje motivacije pozitivno napovedovala preferenco po obvladovanju ciljev. Rezultati so pokazali, da so bili med študenti na Kosovu različni cilji povezani z notranjo motivacijo. Cilji dosežkov so bili diferencirani v zunanji motivaciji z obvladovanjem ciljev, ki je bil precej šibko povezan samo v eni podravni zunanje motivacije.

Ključne besede: cilji dosežkov, Kosovo, motivacija, pričakovanja staršev 


\section{Introduction}

Achievement goals represent an interesting topic of research. Initially, they attracted attention due to the compelling evidence that linked goals to different outcomes. The achievement goals theory postulates that there are two types of goals that foster achievement behaviour in learners (Dweck \& Legget, 1988), namely mastery and performance goals. Mastery goals are reported to endorse learning and understanding while performance goals encourage the demonstration of competences and skills in regard to other learners. Behavioural, cognitive and emotional outcomes differ according to the type of goal endorsed by the learner (Linnenbrink \& Pintrich, 2002).

Maehr and Zusho (2009) propound the view that learners who are mastery approach oriented will be intrinsically motivated, will employ personal standards and will learn from mistakes as much as they learn from successes. In contrast, performance-approach learners will be motivated to perform better than others. Ultimately, students who endorse performance-avoidance goals will only be concerned with not looking incompetent (Linnenbrink \& Pintrich, 2002). There is ample evidence from previous studies that mastery-approach goals are linked to better academic competences and learning, compared to performance goals, which correlate to lower learning and competences (Maehr \& Zusho, 2009). The current literature on achievement goals abounds with examples of studies reporting that learners who endorse mastery-approach goals will be more likely to experience positive emotions (i.e. pride and enjoyment), and will not experience negative emotions. In comparison, existing research validates the view that learners who report performance-approach goals will be more likely to experience negative emotions (i.e. anger and anxiety) (Linnenbrink \& Pintrich, 2002).

Building on the assumption that different outcomes are linked to certain goals the present study explores the link between types of motivation, parental expectations and goal orientations across university students in Kosovo. To that end, the study provides information from a new cultural context, more specifically data from a collectivist culture in which community and family are fundamental. As such, individuality and independence, in contrast to other countries, is not always appreciated and encouraged. Kosovo is underrepresented in international research (Shala \& Grajcevci, 2017) and the present study is the first of its kind in Kosovo to explore goal orientation among university students. Therefore, the data from this study deliver essential insights to practitioners working in the higher education sector in Kosovo. 


\section{Achievement goal theories: An overview}

The existing consensus view in literature is that achievement goals are cognitive constructs that direct the behaviour of learners in achievement situations (Hulleman, Schrager, Bodmann, \& Harackiewicz, 2010). In other words, goals are essential for every activity, because it is goals that give an activity meaning and purpose (Kaplan \& Maher, 2007). To that end, Maehr and Zusho (2009) argue that when a learner states that he or she has the goal to get an A grade then this is an illustration of a goal, but this is not the main interest of achievement goal theories. Instead, achievement goals frameworks are more interested in exploring why a learner wants something, in this example why does a student want an A, and less with what the students want. According to Elliot (1999), understanding what the goal is, is necessary for comprehending whether the learner approaches or avoids the goal itself. As a result, goal theories aim to explain not only the goal endorsed but also in what manner a learner approaches learning situations or avoids not learning a competence. In the example above, achievement goal theories are interested in the behaviour of students (such as completing homework) that would lead to the goal acquisition (e.g. the goal of learning and understanding mathematics) (Maehr \& Zusho, 2009). According to Dweck and Elliot (2005), the behaviour of learners is motivated by the opportunity to show competence or the lack of it. In other words, students who endorse mastery goals will utilise achievement situations to complete personal standards of excellence. In contrast, performance-oriented students will engage in order to outperform other learners.

After more than two decades of research, three theoretical frameworks of achievement goals have been developed (Elliot \& McGregor, 2001). Understandably, theoretical frameworks on goals are different from one another according to what they consider more important, the learner or the situational factors (Dweck \& Elliot, 1983). The initial model of achievement goals differentiated between mastery and performance goals according to the perceptions that learners have regarding intelligence and competence. Learners will adopt mastery goals when they consider intelligence and competence to be both predispositions and changeable constructs. In contrast, learners will develop performance goals if they consider intelligence and competence to be stable traits that do not change (Dweck \& Leggett, 1988). The three-goal model distinguishes between two types of performance goals (performance-approach and performance-avoidance) and mastery goals. The initial two-goal model developed by Dweck, maintains that students can either be performance or mastery oriented (Dweck \& Elliot, 1983). The new model postulates that the learners who adopt 
performance goals can be focused on obtaining positive judgments as well as avoiding negative ones. The new definition of performance goals resulted in the three-goal model that supports the idea that three separate achievement goals exist: performance-approach, performance-avoidance and mastery goals (Elliot \& McGregor, 2001; Hulleman, Scharager, Bodmann, \& Harackiewicz, 2010). The latest model is the $2 \times 2$ model of achievement goals which distinguishes between two types of performance goals (performance-approach and performance-avoidance) and two types of mastery goals-mastery approach and mastery avoidance. This model, however, is not employed in this study.

Mastery-approach goals have traditionally been linked to higher academic competence (Maehr \& Zusho, 2009), higher academic interest (Harackiewicz et al., 2000) and higher achievements (Linnenbrik-Garcia, Tyson, \& Patall, 2008). Performance goals, in contrast, have been reported to correlate to higher emotionality and achievements (Elliot \& McGregor, 2001) similar to mastery-approach goals (Linnenbrik-Garcia et al., 2008). Finally, the available evidence suggests that performance-avoidance goals correlate with less learning, anxiety, as well as low levels of interest and achievement (Elliot \& McGregor, 2001; Maehr \& Zusho, 2009).

\section{Motivation and achievement goals}

Motivation has been a significant topic in education over the years, with educators striving to understand what makes students engaged and motivated. According to existing definitions, motivation represents an inner state that influences behaviour by initiating, directing and maintaining it (Lee, McInerney, Liemc, \& Ortigad, 2010). Literature distinguishes between intrinsic and extrinsic motivation which are considered to be opposite poles of motivation (Lepper, Corpus, \& Iyengar, 2005). According to definitions, intrinsic motivation is the motive that fosters involvement in tasks due to inherent qualities (Lee et al., 2010; Ryan \& Deci, 2000). Intrinsically motivated students possess characteristics of enthusiasm, openness to experience, goal setting and working hard to improve and others. These learners consider tasks to be interesting as well as important which is why they persist in their efforts and employ strategies to achieve goals (Lee et al., 2010).

Extrinsically motivated students remain involved in tasks because of external rewards (Lee et al., 2000; Ryan \& Deci, 2000). Extrinsic motivation is primarily concerned with performance, rewards, praise, and feedback. As such, extrinsically motivated learners employ surface learning and do not engage in tasks for which they foresee no rewards. To illustrate positive rewards, 
for example, good grades will give learners feedback that signals success and competence, which in return increases the chance that the learner will continue engagement in the task. To extrinsically motivated students, negative feedback has a very negative impact because it transmits the idea that the learner is not competent or successful (Lee et al., 2010).

Types of motivation are discussed along with achievement goals because of the reported correlations between goals and motivation types. Achievement goals influence the degree to which students enjoy achievement-related activities, which establishes the correlation between intrinsic motivation and achievement goals (Rawsthorne \& Elliot, 1999). Various research studies support the idea that performance and mastery goals exert different impacts and consequences on intrinsic motivation (Rawsthorne \& Elliot, 1999). Since mastery goals emphasise the intrinsic value of learning (Lee, McInerney, Liem, \& Ortiga, 2010), they have been linked to mastery goals in the literature (Rawsthorne \& Elliot, 1999) and are reported to endorse intrinsic motivation (Dweck, 1986; Nicholls, 1989). Understandably, mastery goals foster intrinsic motivation by promoting challenge, excitement, task involvement (Elliot \& Harackiewicz, 1996; Elliot \& Rawsthorne, 1999), self-determination, and autonomy in learners (Deci \& Ryan, 1985; Dweck, 1986).

Performance goals that emphasise outperforming other students and succeeding with little effort (Lee et al., 2010) have been linked to extrinsic motivation (Rawsthorne \& Elliot, 1999). To put it another way, performance goals limit intrinsic motivation by noting threats, lowering task involvement, as well as increasing anxiety and pressure from evaluations (Elliot \& Harackiewicz, 1996; Elliot \& Rawsthorne, 1999). Unlike mastery goals, performance-avoidance goals generally trigger processes that will decrease intrinsic motivation (Elliot \& Harackiewicz, 1996) because they emphasise anxiety and performance pressure (Harackiewicz, Manderlink, \& Sansone, 1984).

Elliot and Harackiewicz (1996), who are prominent in the literature about achievement goals, reported that $90 \%$ of the studies provided a link between achievement goals and intrinsic motivation, with performance-approach and mastery goals increasing intrinsic motivation. Interestingly, studies concluded that student who endorse performance-approach and mastery goals employ similar levels of intrinsic motivation. The same studies revealed that performance-avoidance goals hinder intrinsic motivation (Elliot \& Harackiewicz, 1996; Rawsthorne \& Elliot, 1999). In contrast, Rawsthoren and Elliot (1999) argue that a number of studies found evidence for the premise that performance-avoidance goals do not hinder intrinsic motivation in addition to the argument that performance-approach goals may not be beneficial to intrinsic 
motivation. Unfortunately, the results of studies have been inconclusive, with some reporting negative effects of performance goals on intrinsic motivation (Harackiewicz, Abrahams, \& Wageman, 1987; Ryan, Koestner, \& Deci, 1991), and other studies failing to support this premise (Harackiewicz \& Elliot, 1993; Koestner, Zuckerman, \& Koestner, 1989).

While achievement goal research has expanded over various topics, few studies have been conducted to assess the impact of different types of intrinsic motivation (Harackiewicz, Barron, \& Elliot, 1998) in achievement goals, and no studies exist in Kosovo. To address this gap in literature, the present study explores the link between types of motivation and achievement goals in a new cultural context. The following hypotheses have been developed for this study:

$\mathrm{H}_{1}$ Intrinsic motivation will be related to mastery goals and performanceapproach goals, while extrinsic motivation will be related to performanceavoidance goals.

$\mathrm{H}_{2}$ Intrinsic motivation will predict mastery goal preferences while extrinsic motivation will predict performance-approach and performanceavoidance goal preferences.

\section{Parental expectations and achievement goals}

To the best of our knowledge, there is a lack of studies focusing on the role of parental expectations in achievement goal endorsement among undergraduate students. However, research has provided ample support for the assertion that parents' expectations tend to be rather crucial in shaping the achievement experiences of children.

The role of parental expectations is fundamental to academic success and, according to Seyfried and Chung (2002), this is a common fact not disputed by researchers. The study conducted by Regner, Loose, and Dumas (2009) suggested that students were aware of their parents' expectations as early as middle school. Given the centrality of this issue, the present research will fill the existing gap in the literature by exploring the impact of parents' expectations on goal endorsement among undergraduate students in Kosovo. The current hypothesis is that:

$\mathrm{H}_{3}$ Parental expectations will be related to preferences for performanceapproach and performance-avoidance goals. 


\section{Method}

\section{Participants}

The study included 600 undergraduate students attending higher education institutions in Kosovo. Participants' ages ranged between 17 and 37 years old $(M=20.64, S D=2.39)$. The sample was comprised of $444(74 \%)$ participants who were attending the public university while a smaller number of participants (156 (26\%) participants) reported attending private institutions. Finally, the sample was predominantly male $(\mathrm{N}=314)$ and included 286 female students.

Table 1

Number of participants according to year of study, gender, and university

\begin{tabular}{lcccccc}
\hline University & F & M & $1^{\text {st }}$ Year $(N)$ & $2^{\text {nd }}$ Year $(N)$ & $3^{\text {rd }}$ Year $(N)$ & N \\
\hline Public University & 218 & 226 & 167 & 188 & 89 & 444 \\
Private Colleges & 68 & 88 & 64 & 68 & 24 & 156 \\
\hline
\end{tabular}

Note. $\mathrm{N}=600$.

The table below provides information for participants according to the year of study, university type, and department. To illustrate, the statistics below provide that the sample included more participants from social science departments, and the public university. The sample also included more first and second years students in comparison to third-year students.

Table 2

Number of participants according to field of study and university

\begin{tabular}{llccc}
\hline \multirow{2}{*}{ University type } & Department & \multicolumn{3}{c}{ Year of study (N) } \\
\cline { 3 - 5 } & & 1 & 2 & 3 \\
\hline \multirow{2}{*}{ Public } & Natural Sciences & 103 & 70 & 48 \\
& Social Sciences & 64 & 118 & 41 \\
\hline \multirow{2}{*}{ Private } & Natural Sciences & 25 & 28 & - \\
& Social Sciences & 39 & 40 & 24 \\
\hline
\end{tabular}

Note. $\mathrm{N}=600$. Exact Sciences: Engineering, Mathematics, Physics etc. Social Sciences: Law, Economics, Sociology, Psychology etc. 


\section{Achievement goals}

Hulleman et al. (2010) reported that two instruments commonly used in achievement goals research are the Achievement Goals Questionnaire (AGS) and Patterns of Adaptive Learning Scales (PALS). The difference between the instruments is their methodology, with AGQ employing normative comparison (e.g. 'My goal in this class is to be better than others') and PALS employing self-representation (e.g. 'One of my goals is to show others that I am good at my class work'), thus resulting in different and incomparable results. The present study utilised the PALS instrument, which assesses three achievement goals through 14 items. Performance-approach goals are assessed by five items such as 'One of my goals is to show others that I am good at my class work'. Performance-avoidance goals were measured with four items, to illustrate 'It is important to me that I do not look stupid in class. Finally, mastery goals were assessed with five items, one of which was, for example, 'It is important to me that I improve my skills this year. The measurement used a five-point scale ranging from 1 (not at all true) to 5 (very true). According to research, PALS, as an instrument, has proven to be reliable and valid (Midgley et al., 2000). The table below shows the internal reliability scores for the scales and subscales, along with the descriptive analysis.

Table 3

Descriptive statistics and Cronbach's $\alpha$ for measures of PALS

\begin{tabular}{lcccccc}
\hline Variable & Cronbach's $\alpha$ & Mean & SD & Possible Range & Skewness & Kurtosis \\
\hline Mastery & .77 & 4.47 & .44 & $1-5$ & -1.04 & 1.43 \\
Performance-approach & .89 & 2.73 & .97 & $1-5$ & .33 & -.67 \\
Performance-avoidance & .72 & 3.23 & .95 & $1-5$ & -.19 & -.66 \\
\hline
\end{tabular}

Note. $\mathrm{N}=600$.

\section{Motivation scales}

Perceptions of intrinsic and extrinsic motivation were assessed by the intrinsic and extrinsic motivation scales (Lepper, Corpus, \& Iyengar, 2005). The instrument included 20 items: twelve of which assessed intrinsic motivation, and eight of which measured extrinsic motivation. The first type of motivation had three subscales: challenge, curiosity, and independent mastery. Challenge was measured with six items, examples of which are 'I like hard work because it is a challenge' and 'I like to go to work that is at a more difficult level.' Curiosity 
was measured with only three items, one of which was 'I work on problems to learn how to solve them'. Lastly, the independent mastery subscale was comprised of three items, an example of which is 'When I make a mistake I like to figure out the right answer by myself'.

Extrinsic motivation included the three subscales of easy work, pleasing the teacher, and dependence on the teacher. The subscale of easy work included three items; one example of items included in this subscale is 'I like easy work that I am sure I can do'. In the subscale of pleasing the teacher, items such as 'I do my school work because the professor tells me to' were used. The final three item subscale used to measure dependence on teacher included items such as 'If I get stuck on a problem I ask the teacher for help'.

A five-point scale, ranging from 1 (strongly disagree) to 5 (strongly agree) was used for the motivation scales. In the original study of Lepper, Corpus, and Iyengar (2005), this motivation instrument had a very high internal consistency vale for intrinsic motivation $(\alpha=.90)$ and a good internal consistency value for the extrinsic motivation scale $(\alpha=.78)$, which resulted in the authors considering the instrument to be valid and reliable (Lepper, Corpus, \& Iyengar, 2005). In the present study, the internal consistency for the intrinsic scale was higher $(\alpha=.82)$ compared to the consistency of the extrinsic motivation scale $(\alpha=.69)$.

Table 4

Descriptive statistics and Cronbach's $\alpha$ for measures of motivation

\begin{tabular}{lcccccc}
\hline Variable & Cronbach's $\alpha$ & Mean & SD & Possible Range & Skewness & Kurtosis \\
\hline Intrinsic Motivation & .82 & 4.17 & .50 & $1-5$ & -.77 & 1.56 \\
- Challenge & .80 & 4.16 & .59 & $1-5$ & -.93 & 1.94 \\
- Curiosity & .55 & 4.28 & .53 & $1-5$ & -.87 & 1.56 \\
- Independent mastery & .66 & 4.08 & .71 & $1-5$ & -.87 & .85 \\
\hline Extrinsic Motivation & .69 & 3.22 & .61 & $1-5$ & -.08 & .03 \\
- Easy Work & .56 & 2.87 & .81 & $1-5$ & .27 & -.02 \\
- Pleasing the teacher & .20 & 2.88 & 1.05 & $1-5$ & .01 & -.83 \\
- Dependence on teacher & .66 & 3.80 & .74 & $1-5$ & -.66 & .50 \\
\hline
\end{tabular}

Note. $\mathrm{N}=600$.

\section{Parental Expectations}

To measure parental expectations, nine items were adopted from the PISA study (PISA, 2003). Example items from the measure included 'My parents expect me to delve deeply into studying' and 'Even though I make a great 
effort in my studies, my parents are never completely satisfied with my efforts'. Five of the nine questions that were adopted included the word 'science' in the original item; however, in order to be able to use the items, the word 'science' was replaced with the word 'studying'. An example of the initial item is 'In our family, science is very important'; after the word replacement it was 'In our family, studying is very important'. As in the previous measures, a five-point scale was used ranging from 1 (strongly disagree) to 5 (strongly agree). The Cronbach $\alpha$ for the interest measure was $\alpha=.88(\mathrm{M}=3.84, \mathrm{SD}=.45)$.

\section{Results}

Hypothesis 1 states that intrinsic motivation will be related to mastery goals and performance-approach goals, while extrinsic motivation will be related to performance-avoidance goals. To test this hypothesis, two Pearson correlation analyses were conducted to separately measure the correlation of achievement goals with intrinsic and extrinsic motivation. The results showed a positive correlation between intrinsic motivation and mastery goals $(\mathrm{r}=.45, \mathrm{p}<.01)$. The intrinsic motivation scale contained three subscales measuring challenge, curiosity, and mastery. The endorsement of mastery-approach goals was positively related to the need for challenge $(\mathrm{r}=.38, \mathrm{p}<.01)$, curiosity $(\mathrm{r}=.45, \mathrm{p}<.01)$, and mastery $(\mathrm{r}=.30, \mathrm{p}<.01)$. Performance-approach goals, as expected, were positively related to intrinsic motivation $(\mathrm{r}=.20, \mathrm{p}<.01)$, and in terms of subscales, also positively related to challenge $(\mathrm{r}=.19, \mathrm{p}<.01)$, curiosity $(\mathrm{r}=.17, \mathrm{p}<.01)$ and mastery $(\mathrm{r}=.12, \mathrm{p}<.01)$.

Performance-avoidance goals, in contrast, showed some interesting results because they documented positive correlation with intrinsic motivation as a scale but also with the subscales of intrinsic motivation. Performance-avoidance goals were positively correlated with intrinsic motivation $(r=.15, \mathrm{p}<.01)$ as well as with the subscales of intrinsic motivation, namely challenge $(r=.12$, $\mathrm{p}<.01)$, curiosity $(\mathrm{r}=.15, \mathrm{p}<.01)$ and mastery $(\mathrm{r}=.11, \mathrm{p}<.01)$. 
Table 5

Pearson Correlation Matrix between achievement goals and intrinsic motivation

\begin{tabular}{lcccccc}
\hline & 1 & 2 & 3 & 4 & 5 & 6 \\
\hline 1. Performance-approach & - & & & & & \\
2. Performance avoidance & $.62^{* *}$ & - & & & & \\
3. Mastery & $.13^{* *}$ & $.21^{* *}$ & - & & & \\
4. Intrinsic Motivation & $.20^{* *}$ & $.15^{* *}$ & $.45^{* *}$ & - & & \\
5. Intrinsic Challenge & $.19^{* *}$ & $.12^{* *}$ & $.38^{* *}$ & $.91^{* *}$ & - & \\
6. Intrinsic Curiosity & $.17^{* *}$ & $.15^{* *}$ & $.45^{* *}$ & $.74^{* *}$ & $.56^{* *}$ & - \\
7. Intrinsic Mastery & $.12^{* *}$ & $.11^{* *}$ & $.30^{* *}$ & $.72^{* *}$ & $.47^{* *}$ & $.39^{* *}$ \\
\hline
\end{tabular}

Note. ${ }^{*} \mathrm{p}<.05 .{ }^{* *} \mathrm{p}<.01$.

The second part of this hypothesis states that extrinsic motivation will be correlated to performance-avoidance goals, which, as expected, showed significant positive correlations with extrinsic motivation $(r=.35, p<.01)$ in general and with the three subscales: extrinsic motivation $(r=.23, p<.01)$, pleasing the teacher $(\mathrm{r}=.31, \mathrm{p}<.01)$, and dependence on the teacher $(\mathrm{r}=.23$, $\mathrm{p}<.01$ ). Surprisingly, the correlation analysis showed a positive correlation between mastery goals and extrinsic motivation $(\mathrm{r}=.15, \mathrm{p}<.01)$, but only with the subscale of dependence on the teacher $(r=.24, p<.01)$. The results of the correlation analysis prove that all types of goals positively correlate to all types of intrinsic motivation, but the correlation values for performance-approach and performance-avoidance goals are lower. In contrast, the performance-approach and performance goals strongly correlate to all subscales of extrinsic motivation, but mastery goals correlate only to the subscale of dependence on the teacher.

Table 6

Pearson Correlation Matrix between achievement goals and extrinsic motivation

\begin{tabular}{lcccccc}
\hline & 1 & 2 & 3 & 4 & 5 & 6 \\
\hline 1. Perfonmance-approach & - & & & & & \\
2. Performance avoidance & $.62^{* *}$ & - & & & & \\
3. Mastery & $.13^{* *}$ & $.21^{* *}$ & - & & & \\
4. Extrinsic Motivation & $.45^{* *}$ & $.35^{* *}$ & $.15^{* *}$ & - & & \\
5. Extrinsic Work & $.28^{* *}$ & $.23^{* *}$ & .02 & $.76^{* *}$ & - & \\
6. Pleasing Teacher & $.37^{* *}$ & $.31^{* *}$ & .07 & $.78^{* *}$ & $.47^{* *}$ & - \\
7. Dependence on Teacher & $.34^{* *}$ & $.23^{* *}$ & $.24^{* *}$ & $.63^{* *}$ & $.13^{* *}$ & $.27^{* *}$ \\
\hline
\end{tabular}

Note. ${ }^{*} p<.05 .{ }^{* *} p<.01$. 
Hypothesis 2 states that intrinsic motivation will predict mastery goal preferences while extrinsic motivation will predict performance-approach and performance-avoidance goal preferences. The results of linear regression analyses revealed that the subscale of curiosity in intrinsic motivation predicted mastery goals while accounting for $21 \%$ of the variance in mastery goal adaptation.

Table 7

Summary of simple regression analysis for mastery goals

\begin{tabular}{cccccc}
\hline Variable & B & SB(B) & $\beta$ & $T$ & Sig. $(p)$ \\
\hline Curiosity & 0.37 & 0.30 & 0.45 & 12.34 & .000 \\
\hline
\end{tabular}

Note. $\mathrm{R}^{2}=.21$.

Extrinsic motivation predicted performance-approach goals, accounting for $20 \%$ of the variance.

Table 8

Summary of simple regression analysis for performance-approach goals

\begin{tabular}{lccccc}
\hline Variable & B & SB(B) & $\beta$ & $T$ & Sig. $(p)$ \\
\hline Extrinsic Motivation & 0.37 & 0.30 & .45 & 12.34 & .000 \\
\hline
\end{tabular}

Note. $\mathrm{R}^{2}=.20$.

Additionally, extrinsic motivation was a predictor for performanceavoidance goals, accounting for $14 \%$ of the variance. The results of the linear regression analysis have supported this hypothesis.

Table 9

Summary of simple regression analysis for performance-avoidance goals

\begin{tabular}{lccccc}
\hline Variable & B & SB(B) & $\beta$ & $T$ & Sig. $(p)$ \\
\hline Extrinsic Motivation & 0.54 & 0.06 & 0.35 & 9.21 & .000 \\
\hline
\end{tabular}

Note. $\mathrm{R}^{2}=.14$.

\section{Parental Expectations and achievement goals}

Hypothesis 3 states that parental expectations will be related to the preferences for performance-approach and performance-avoidance goals. The results, as expected, showed positive correlations between parental expectations and 
performance goal orientations. Specifically, it is suggested that the higher the parental expectations are, the more performance-approach-oriented the student will be $(\mathrm{r}=.40, \mathrm{p}<.01)$. Interestingly the other type of performance goals, the performance-avoidance also showed a positive correlation with parent expectations $(\mathrm{r}=.34, \mathrm{p}<.01)$. Additionally, a positive correlation can also be observed between parental expectations and the endorsement of mastery goals $(\mathrm{r}=.35, \mathrm{p}<.01)$. The results documented positive correlations between both types of performance goals and parental expectations. Unexpectedly, the results showed a positive correlation between the endorsement of mastery goals and perceived parental expectations.

Table 10

Pearson Correlation Matrix between achievement goals and parental expectations

\begin{tabular}{lcccc}
\hline & 1 & 2 & 3 & 4 \\
\hline 1. Performance-Approach & - & & & \\
2. Performance-Avoidance & $.62^{* *}$ & - & & \\
3. Mastery & $.13^{* *}$ & $.21^{* *}$ & - & \\
4. Parental Expectations & $.40^{* *}$ & $.34^{* *}$ & $.35^{* *}$ & - \\
\hline
\end{tabular}

Note. ${ }^{*} \mathrm{p}<.05 .{ }^{* *} \mathrm{p}<.01$.

\section{Discussion}

The present study focused on assessing the link between parental expectations, intrinsic and extrinsic motivation and achievement goals in university students in Kosovo. Intrinsic motivation is considered to be the motive which keeps students engaged in a task due to inherent qualities (Lee et al., 2010; Ryan \& Deci, 2000). Students who are intrinsically motivated are enthusiastic, open to experiencing adventures, striving for excellence, set goals, as well as work hard to improve. Typically, students who are intrinsically motivated tend to think of tasks as interesting and important, which in return makes it possible for them to persist in their work as well as develop strategies to achieve goals (Lee et al., 2010). A considerable number of research studies on the topic of achievement and motivation argue that mastery and performance goals are different processes that also have different impacts and consequences on intrinsic motivation (Rawsthorne \& Elliot, 1999). To date, research has supported the assumption that mastery goals are linked to intrinsic motivation (Elliot \& Harackiewicz, 1999; Rawsthorne \& Elliot, 1999) due to their focus on the intrinsic value of 
learning (Lee et al., 2010). As expected, mastery goals among university students in Kosovo correlated highly to all subscales of intrinsic motivation. It was unexpected that performance-approach and performance-avoidance also correlated to intrinsic motivation; however, the correlation values were significantly lower compared to the mastery goals. Additionally, curiosity as a subscale of intrinsic motivation predicted mastery goal endorsement while accounting for $21 \%$ of the variance. The results of this study imply that among students in Kosovo mastery goals are linked to intrinsic motivation. To that end, the results support the understanding that other goals, while correlating to intrinsic motivation, exhibit low correlation values compared to mastery goals. It is a unique conclusion of this study that among students in Kosovo, curiosity predicted preference for mastery goals which implies that curiosity is a strong determinant of mastery goal endorsement. In addition, the findings of this study imply that students who employ performance goals are the ones who have low levels of intrinsic motivation. To that end, performance-oriented students may benefit greatly from instruction and evaluation that fosters intrinsic motivation.

In contrast, extrinsic motivation is the motive that keeps students engaged in a task through external rewards (Lee et al., 2010; Ryan \& Deci, 2000). Extrinsic motivation is related to worrying about grades, rewards, praise, and feedback. Students who are extrinsically motivated tend to engage in surface learning and will usually not continue in a task when they perceive that there will be no extrinsic rewards. Research studies maintain that performance goals seem to be connected to extrinsic motivation (Elliot \& Harackiewicz, 1999; Rawsthorne \& Elliot, 1999) due to the focus on doing better than others and achieving success with little effort (Lee et al., 2010). Similar to existing studies the results of the present research provided that performance-approach and performance-avoidance goals correlated positively to extrinsic motivation. Mastery goals correlated positively to the subscale of dependence on the teacher. Furthermore, extrinsic motivation predicted a preference for performanceapproach goals as well as performance-avoidance goals. The present study conducted on students attending higher education institutions in Kosovo adds to the existing literature by supporting the link between extrinsic motivation and performance goals. However, the present study expands knowledge of the field by documenting that extrinsic motivation predicts performance-approach and performance-avoidance goal preferences. To that end, the results of this study imply that education settings which foster extrinsic motivation will also endorse the adoption of performance goals. Consequently, education approaches and settings in Kosovo ought to be altered to ensure that they foster intrinsic motivation instead of extrinsic approaches to learning. 
Regarding the link between achievement goals and parental expectations, the data provide that the latter exhibit positive correlations to all types of achievement goals. To that end, the strongest link was noticeable between parental expectations and performance-approach goals, followed by mastery goals and finally performance-avoidance goals. This finding implies that parents who expect their children to perform well will ultimately 'teach' their children to adopt performance-approach goals. Understandably, this result documents the vital influence that parents have over their children's approach to learning.

\section{Limitations of the study and future research}

The present study used three self-reporting instruments to assess achievement goals, motivation, and parental expectations in students in Kosovo, which may be considered a limitation. However, the study is the first of its kind to assess motivation and achievement in students in Kosovo, which is why it provides useful information to researchers and practitioners working in the field of higher education in that country. Future studies should expand the area of study by researching the link between types of goals and intrinsic and extrinsic motivation, specifically by exploring the impact of intrinsic motivation on mastery goals and vice versa. There is also an evident need to understand the strength of the correlation between extrinsic motivation on one hand and performance-approach and performance-avoidance goals on the other.

\section{References}

Deci, E. L., \& Ryan, R. M. (1985). Intrinsic motivation and self-determination in human behavior. New York, NY: Plenum.

Dweck, C. S. (1986). Motivational processes affecting learning. American Psychologist, 41(10), 10401048 .

Dweck, C. S., \& Elliot, E. S. (1983). Achievement motivation. In P. Mussen \& E. M. Hatherington (Eds.), Handbook of child psychology (pp. 643-691). New York, NY: Wiley.

Dweck, C. S., \& Leggett, E. L. (1988). A social-cognitive approach to motivation and personality. Psychological Review, 95(2), 256-273.

Elliot, A. J. (1999). Approach and voidance motivation and achievement goals. Educational Psychologist, 34(3), 169-189.

Elliot, E. S., \& Dweck, C. S. (2005). Competence and motivation: Competence as the core of achievement motivation. In E. S. Elliot \& C. S. Dweck, Handbook of competence and motivation (pp. 3-12). New York, NY: The Guilford Press. 
Elliot, A. J., \& Harackiewicz, J. M. (1996). Approach and avoidance achievement goals and intrinsic motivation: A mediational analysis. Journal of Personality and Social Psychology, 7o(3), 461-475.

Elliot, A. J., \& McGregor, H. A. (2001). A 2 X 2 achievement goal framework. Journal of Personality and Social Psychology, 8o(3), 501-519.

Harackiewicz, J. M., Abrahams, S., \& Wageman, R. (1987). Performance evaluation and intrinsic motivation: The effects of evaluative focus, rewards, and achievement orientation. Journal of Personality and Social Psychology, 53(6), 1015-1023.

Harackiewicz, J. M., Barron, K. E., \& Elliot, A. J. (1998). Rethinking achievement goals: When are they adaptive for college students and why? Educational Psychologist, 33, 1-21.

Harackiewicz, J. M., Barron, K. E., Tauer, J. M., Carter, S. M., \& Elliot, A. J. (200o). Short-term and long-term consequences of achievement goals: Predicting interest and performance over time. Journal of Educational Psychology, 92(2), 316-2000.

Harackiewicz, J. M., \& Elliot, A. J. (1993). Achievement goals and intrinsic motivation. Journal of' Personality and Social Psychology, 65, 904-915.

Harackiewicz, J. M., Manderlink, G., \& Sansone, C. (1984). Rewarding pinball wizardry: Effects of evaluation and cue value on intrinsic interest. Journal of Personality and Social Psychology, 47(2), 287-300.

Hulleman, C. S., Schrager, S. M., Bodmann, S. M., \& Harackiewicz, J. M. (2010). A meta analytic review of achievement goal measure: Different labels for the same constructs or different constructs with similar labels? Psychological Bulletin, 136(3), 422-449.

Kaplan, A., \& Maehr, M. L. (2007). The contributions and prospects of goal orientation theory. Educational Psychology Review, 19, 141-184.

Koestner, R., Zuckerman, M., \& Koestner, J. (1989). Attributional focus of praise and children's intrinsic motivation: The moderating role of gender. Personality and Social Psychology Bulletin, 15(1), 61-72.

Lee, J. Q., McInerney, D. M., Liemc, G. A., \& Ortigad, Y. P. (2010). The relationship between future goals and achievement goals: An intrinsic-extrinsic motivation perspective. Contemporary Educational Psychology, 35(4), 264-279.

Lepper, M. R., Corpus, J. H., \& Iyengar, S. S. (2005). Intrinsic and extrinsic motivational orientations in the classroom: Age differences and academic correlations. Journal of Educational Psychology, 97(2), $184-196$.

Linnenbrik-Garcia, L., Tyson, D. F., \& Patall, E. A. (2008). When are achievement goal orientation beneficial for achievement? A closer look at moderating factors. International Review of Social Psychology, 21(1-2), 19070.

Maehr, M. L., \& Zusho, A. (2009). Achievement goal theory: The past, present, and future. In K. R. Wentzel \& A. Wigfield (Eds.), Handbook of motivation in school (pp. 1-104). New York, NY: Taylor Francis.

Midgley, C., Maehr, M. L., Anderman, E. M., Anderman, L. K., et al. (200o). Manual for the Patterns of Adaptive Learning Scales (PALS). Ann Arbor, MI: University of Michigan.

Nicholls, J. G. (1989). The competitive ethos and democratic education. Cambridge, MA: Harvard 
University Press.

Rawsthorne, L. J., \& Elliot, A. J. (1999). Achievement goals and intrinsic motivation: A meta-analytic review. Personality and Social Psychology Review, 3(4), 326-344.

Regner, I., Loose, F., \& Dumas, F. (2009). Students' perceptions of parental and teacher academic involvement: Consequences on achievement goals. European Journal of Psychology of Education, 14(2), $263-277$.

Ryan R. M., \& Deci E. L. (200o). Self-determination theory and the facilitation of intrinsic motivation, social development, and well-being. American Psychologist, 55(1), 68-78.

Ryan, R. M., Koestner, R., \& Deci, E. L. (1991). Ego-involved persistence: When free-choice behavior is not intrinsically motivated. Motivation and Emotion, 15(3), 185-205.

Seyfried, S. F., \& Chung, I. J. (2002). Parent involvement as parental monitoring of student motivation and parent expectations predicting later achievement among African American and European American middle school age students. Retrieved from http://www.haworthpress.com/store/product.asp?sku=Jo51 Shala, A., \& Grajcevci (2017). Digital competencies among student populations in Kosovo: the impact of inclusion, socioeconomic status, ethnicity and type of residence. Education and Information Technologies. Advance online publication. Retrieved from https://doi.org/10.1007/s10639-017-9657-3 Tamir, M., \& Diener, E. (2008). Approach-avoidance goals and well-being: One size does not fit all. In A. J. Elliot (Ed.), Handbook of approach and avoidance motivation (pp. 415-427). New York, NY: Psychology Press.

\section{Biographical note}

Albulene Grajcevci, is a Researcher at the Professional Development Institute in Prishtina, Kosovo. She holds degrees from the Ludwig Maximilians University in Munich (Germany) and the University of Prishtina (Kosovo). Her expertise is in educational psychology, with a special focus on achievement goals, achievement emotions, organizational learning and computer enhanced learning.

Arif Shala, PhD, is a Researcher at the Professional Development Institute in Prishtina, Kosovo. He holds a $\mathrm{PhD}$ in Education from the Ludwig Maximilians University, Munich (Germany). His expertise is in educational science, with a specific focus on 21st Century skills, student performance, learning in the new era, online learning and inclusion. 